\title{
PENGARUH TINGKAT KEPATUHAN WAJIB PAJAK ORANG PRIBADI TERHADAP PENERIMAAN PAJAK PADA KPP BITUNG
}

\author{
Oleh: \\ Regina Laurensana Tuwaidan \\ Jullie J. Sondakh \\ Inggriani Elim \\ Fakultas Ekonomi dan Bisnis, Jurusan Akuntansi \\ Universitas Sam Ratulangi Manado \\ e-mail: regina.laurensana@ymail.com
}

\begin{abstract}
ABSTRAK
Sumber penerimaan negara yang digunakan untuk membiayai pengeluaran pemerintah dan pembangunan salah satunya adalah pajak. Penerimaan pajak secara tidak langsung bertujuan untuk meningkatkan kemakmuran dan kesejahteraan masyarakat. Penelitian ini bertujuan untuk mengetahui pengaruh tingkat kepatuhan wajib pajak orang pribadi terhadap penerimaan pajak penghasilan pasal 25. Objek penelitian skripsi ini adalah kantor pelayanan pajak pratama Bitung. Tugas dari Kantor pelayanan pajak Bitung adalah melaksanakan tugas pokok Direktorat Jenderal Pajak dalam penerimaan negara. Penelitian ini menggunakan analisis stastistik regresi linier sederhana serta menggunakan data sekunder yaitu surat setoran pajak yang masuk tepat waktu dan jumlah penerimaan pajak penghasilan pasal 25 dikantor pelayanan pajak Bitung dari bulan januari 2009 sampai dengan juli 2012. Hasil penelitian diketahui bahwa tingkat kepatuhan wajib pajak orang pribadi tidak berpengaruh signifikan terhadap penerimaan pajak penghasilan pasal 25. Hal ini disebabkan karena masih kurang adanya kesadaran masyarakat di kota Bitung terhadap pentingya membayar pajak secara tepat waktu dan jumlah surat setoran pajak (SSP) yang masuk tepat waktu terdapat laporan perhitungan pajaknya yang nihil.
\end{abstract}

Kata kunci : wajib pajak, penerimaan pajak, PPh.

\begin{abstract}
State Revenue sources used to funance goverment ecpenditure and development one of which is taxes. Tax revenues indirectly aimed at improving the welfare and prosperity of the community. Thus study aimed to determine the influence of level of private taxpayer to the receipt of income tax article . The duty of Manado Primary Tax Office is to perform the basic tasks of Directorate General Of Taxation in Country's revenue. This study uses is the analytical method used is simple linier regression statical analysis and also use the secondary data is the tax letter of incoming payment on time and the amount of income tax article payer which is registered in Bitung Primary Tax Office from january 2009 until july 2012. The research results reveals that the level of complience of private taxpayer amount has no significant effect to the receipt of income tax article . This is because they lack the awareness of the public in the Bitung city the importance of paying on time and the tax letter of incoming payment on time there are reports of naught calculation tax.
\end{abstract}

Keywords : taxpayers, tax revenue, income tax. 


\section{Latar Belakang}

\section{PENDAHULUAN}

Sumber penerimaan negara yang digunakan untuk membiayai pengeluaran pemerintah dan pembangunan nasional salah satunya adalah pajak. Penerimaan pajak secara tidak langsung bertujuan untuk meningkatkan kemakmuran dan kesejahteraan masyarakat. Adriani menyatakan pajak adalah iuran masyarakat kepada negara (yang dapat dipaksakan) yang terutang oleh yang wajib membayarnya menurut peraturan-peraturan dengan tidak mendapat prestasi kembali yang langsung dapat ditunjuk dan yang gunanya adalah untuk membiayai pengeluaran-pengeluaran umum berhubungan dengan tugas negara untuk menyelenggarakan pemerintahan (Widyaningsih, $2011: 2$ ).

Pemungutan pajak memang bukan suatu pekerjaan yang mudah, disamping peran serta aktif dari aparat pajak, juga dituntut kemauan dari para wajib pajak itu sendiri. Dimana pemungutan pajak di Indonesia mengacu pada sistem self assessement. Sistem self assessment adalah sistem pemungutan pajak yang memberi wewenang, kepercayaan, tanggung jawab kepada wajib pajak untuk menghitung, memperhitungkan, membayar dan melaporkan sendiri besarnya pajak yang harus dibayar. Sesuai dengan sistem self assessement, setiap wajib pajak membayar pajak yang terutang sesuai dengan ketentuan peraturan perundang-undangan perpajakan, dengan tidak menggantungkan pada adanya surat ketetapan pajak (Casavera, $2009: 3$ ).

Kepatuhan pajak yang bersumber dari kesadaran masyarakat terhadap penunaian kewajiban membayar pajak itu tentu bukan sesuatu yang berdiri sendiri. Berbagai persoalan perpajakan yang kerap muncul, baik yang bersumber dari wajib pajak (masyarakat), fiskus sebagai aparatur pajak, maupun yang bersumber dari sistem perpajakan itu sendiri. Kriteria wajib pajak dikatakan patuh, yakni tepat waktu dalam membayar pajak, tidak mempunyai tunggakan pajak, dan pengisian SSP mendekati kebenaran, atau tidak melenceng jauh dari pada semestinya .

Penelitian ini dilakukan pada Kantor Pelayanan Pajak di Bitung, disebabkan oleh karena tingkat kepatuhan wajib pajak yang ada atau terdaftar pada KPP di Bitung masih rendah. Bisa dilihat bahwa jumlah wajib pajak orang pribadi pada tahun 2009 sebesar 44.319 dan wajib pajak yang menyetor pajak atau mengisi Surat Setoran Pajak (SSP) hanya sebesar 8.152 atau 18\% dari wajib pajak yang menyetor pajaknya , pada tahun 2010 jumlah wajib pajak orang pribadi pada tahun 2010 sebesar 14.084 dan wajib pajak yang menyetor pajak atau mengisi Surat Setoran Pajak (SSP) hanya sebesar 11.201 atau $79 \%$ dari wajib pajak yang menyetor pajaknya, dan pada tahun 2011 jumlah wajib pajak orang pribadi pada tahun 2011 sebesar 10.213 dan wajib pajak yang menyetor pajak atau mengisi Surat Setoran Pajak (SSP) sebesar 9.966 atau 97\% dari wajib pajak yang menyetor pajaknya, serta tahun 2012 jumlah wajib pajak orang pribadi pada tahun 2012 sebesar 6.355 dan wajib pajak yang menyetor pajak atau mengisi Surat Setoran Pajak (SSP) sebesar 5.322 atau 83\% dari wajib pajak yang menyetor pajaknya. Maka dapat disimpulkan bahwa pada tahun 2009 wajib pajak yang membayar pajak tidak lebih dari setengah atau hanya $18 \%$ dari wajib pajak yang terdaftar di Kantor Pelayanan Pajak Bitung dan pada tahun 2010 sebesar 79\%, pada tahun 2011 sebesar 97\%, dan sampai dengan tahun 2012 sebesar $83 \%$ wajib pajak yang membayar pajak sudah lebih dari setengah tetapi tidak mencapai jumlah wajib pajak yang terdaftar di Kantor Pelayanan Pajak Bitung. Sehingga tingkat kepatuhan wajib pajak orang pribadi di Kantor Pelayanan Pajak Bitung masih rendah.

\section{Tujuan Penelitian}

Tujuan dari penelitian ini adalah untuk mengetahui pengaruh tingkat kepatuhan wajib pajak orang pribadi terhadap penerimaan pajak pada Kantor Pelayanan Pajak di Bitung.

\section{Pajak}

\section{TINJAUAN PUSTAKA}

Adriani menyatakan pajak adalah iuran masyarkat kepada negara (yang dapat dipaksakan) yang terutang oleh yang wajib membayaranya menurut peraturan-peraturan umum (undang-undang) dengan tidak mendapat prestasi kembali yang langsung dapat ditunjuk dan yang gunanya adalah untuk membiayai pengeluaranpengeluaran umum berhubung tugas negara untuk menyelenggarakan pemerintahan (Pudyatmoko,2009: 3 ).

\section{Syarat Pemungutan Pajak}

Pembebanan pajak pada masyarakat tidaklah mudah. Bila terlalu tinggi, masyarakat akan enggan membayar pajak. Namun bila terlalu rendah, maka pembangunan tidak akan berjalan karena dana yang kurang. Agar tidak menimbulkan berbagai masalah, maka pemungutan pajak harus memenuhi persyaratan (Sumarsan, 2012 : 7), yaitu : 
1. Pemungutan pajak harus adil.

2. Pungutan pajak tidak mengganggu perekonomian.

3. Pemungutan pajak harus efisien.

4. Sistem pemungutan pajak harus sederhana

\section{Tarif Pajak}

Struktur tarif yang berhubungan dengan pola presentase tarif pajak dikenal 4 ( empat) macam tarif, (Waluyo, $2011: 18$ ) adalah sebagai berikut :

1. Tarif Pajak Proposional/Sebanding.

Tarif pajak proposional yaitu tarif pajak yang berupa presentase tetap terhadap jumlah berapa pun yang menjadi dasar pengenaan pajak.

2. Tarif Pajak Progresif.

Tarif pajak progresif yaitu tarif pajak yang prensentasenya menjadi lebih besar apabila jumlah yang menjadi dasar pengenaannya semakin besar.

3. Tarif Pajak Degresif.

Tarif pajak degresif adalah presentase tarif pajak yang semakin menurun apabila jumlah yang menjadi dasar pengenaan pajak menjadi semakin besar.

4. Tarif Pajak Tetap.

Dalam tarif pajak tetap ini adalah tarif berupa jumlah yang tetap (sama besarnya) terhadap berapa pun jumlah yang menjadi dasar pengenaan pajak. Oleh karena itu, besarnya pajak yang teruatang adalah tetap.

\section{Surat Setoran Pajak (SSP)}

UU No. 28 tahun 2007 tentang perubahan ketiga atas Undang-undang No. 6 tahun 1983 tentang ketentuan umum dan tata cara perpajakan menyatakan bahwa Surat Setoran Pajak adalah bukti pembayaran atau penyetoran pajak yang telah dilakukan dengan menggunakan formulir atau telah dilakukan dengan cara lain ke kas negara melalui Kantor Pos dan Bank Persepsi (Sumarsan, 2012 : 53).

\section{PPh Pasal 25}

Pajak penghasilan pasal 25 adalah angsuran pajak penghasilan dalam tahun pajak berjalan yang harus dibayar sendiri oleh wajib pajak untuk setiap bulan dalam tahun pajak yang berjalan (Waluyo, 2011 : 305). Angsuran pajak pasal 25 tersebut dapat dijadikan sebagai kredit pajak terhadap pajak yang terutang atas seluruh penghasilan wajib pajak pada akhir tahun pajak yang dilaporkan dalam Surat Pemberitahuan (SPT) tahunan pajak penghasilan (Lubis, et al. 2010 : 144).

\section{Kepatuhan Wajib Pajak}

Sistem pemungutan pajak yang digunakan di Indonesia adalah self assessment maka wajib pajak harus aktif memenuhi kewaiban perpajakannya mulai dari mendaftrakan diri, mengisi SPT dengan jujur, baik benar sampai dengan melunasi pajak terutang (Rahman, $2010: 23$ ). Walaupun sudah tersedia ancaman hukuman administratif maupun ancaman hukum pidana bagi wajib pajak yang tidak memenuhi kewajiban perpajakannya. Kepatuhan perpajakan dapat didefinisikan sebagai suatu keadaan dimana wajib pajak memenuhi semua kewajiban perpajakan dan melaksanakan hak perpajakannya.

Kepatuhan ada dua macam yaitu kepatuhan formal dan kepatuhan material. Kepatuhan formal adalah suatu keadaan dimana wajib pajak memenuhi kewajiban perpajakan secara formal sesuai dengan ketentuan dalam undang-undang perpajakan. Misalnya ketentuan tentang batas waktu penyampaian SPT Tahunan. Sedangkan kepatuhan material adalah suatu keadaan dimana wajib pajak secara substansi/hakekat memenuhi semua ketentuan material perpajakan. Kepatuhan material dapat meliputi kepatuhan formal. Jadi wajib pajak yang memenuhi kepatuhan material dalam mengisi SPT Tahunan Pajak Penghasilan, adalah wajib pajak yang mengisi dengan jujur, baik dan benar SPT tersebut sesuai dengan ketentuan dalam undang-undang perpajakan dan menyampaikan ke Kantor Pelayanan Pajak sebelum batas waktu. 


\section{Penelitian Terdahulu}

Tabel.1 Penelitian Terdahulu

\begin{tabular}{|c|c|c|c|c|c|c|}
\hline $\begin{array}{l}\text { Nama } \\
\text { Peneliti/Tahun }\end{array}$ & Judul & Tujuan & $\begin{array}{l}\text { Metode } \\
\text { Penelitian } \\
\end{array}$ & Hasil Penelitian & Persamaan & Perbedaan \\
\hline $\begin{array}{l}\text { Lainutu } \\
(2013)\end{array}$ & $\begin{array}{l}\text { Pengaruh } \\
\text { jumlah wajib } \\
\text { pajak PPh } \\
\text { Pasal } 21 \\
\text { terhadap } \\
\text { penerimaan } \\
\text { PPh pasal } 21 \\
\text { pada KPP } \\
\text { Pratama } \\
\text { Manado }\end{array}$ & $\begin{array}{l}\text { Untuk } \\
\text { menganalisis } \\
\text { pengaruh } \\
\text { jumlah wajib } \\
\text { pajak PPh } \\
\text { pasal } 21 \\
\text { orang } \\
\text { pribadi } \\
\text { terhadap } \\
\text { penerimaan } \\
\text { PPh pasal } \\
21 .\end{array}$ & $\begin{array}{l}\text { Analisis } \\
\text { Regresi } \\
\text { Linier } \\
\text { Sederhana }\end{array}$ & $\begin{array}{l}\text { Jumlah } \\
\text { pajak PPH pasal } \\
21 \text { Orang pribadi } \\
\text { berpengaruh } \\
\text { signifikan } \\
\text { terhadap } \\
\text { penerimaan } \mathrm{PPh} \\
\text { Pasal 21 }\end{array}$ & $\begin{array}{l}\text { Peneliti } \\
\text { sebelumnya } \\
\text { menggunakan } \\
\text { pembahasan } \\
\text { tentang wajib } \\
\text { pajak dan } \\
\text { penerimaan } \\
\text { pajak di KPP } \\
\text { Pratama }\end{array}$ & $\begin{array}{ll}\text { Objek peneliti } \\
\text { sebelumnya } \\
\text { menggunakan } \\
\text { variabel terikat yauti } \\
\text { penerimaan } \\
\text { Pasal 21 }\end{array}$ \\
\hline $\begin{array}{l}\text { Pangemanan } \\
(2013)\end{array}$ & $\begin{array}{l}\text { Hubungan } \\
\text { jumah dan } \\
\text { kepatuhan } \\
\text { wajib pajak } \\
\text { badan } \\
\text { dengan } \\
\text { penerimaan } \\
\text { PPh KPP } \\
\text { Pratama } \\
\text { Manado }\end{array}$ & $\begin{array}{l}\text { Untuk } \\
\text { melihat } \\
\text { seberapa } \\
\text { kuat } \\
\text { hubungan } \\
\text { antara } \\
\text { jumlah dan } \\
\text { kepatuhan } \\
\text { wajib pajak } \\
\text { badan } \\
\text { dengan } \\
\text { penerimaan } \\
\text { PPh di KPP } \\
\text { Pratama } \\
\text { Manado }\end{array}$ & $\begin{array}{l}\text { Analisis } \\
\text { korelasi } \\
\text { berganda }\end{array}$ & $\begin{array}{l}\text { Kepatuhan wajib } \\
\text { pajak badan } \\
\text { dalam hal ini } \\
\text { pelaporasn SPT } \\
\text { Tahunan tidak } \\
\text { mendukung } \\
\text { adanya variabel } \\
\text { tersebut dengan } \\
\text { alasan } \\
\text { kemungkinan } \\
\text { adanya pelaporan } \\
\text { yang terlambat } \\
\text { dan tidak riil }\end{array}$ & $\begin{array}{l}\text { Penelitian } \\
\text { sebelumnya } \\
\text { pembhasan } \\
\text { mengenai hal- } \\
\text { hal yang } \\
\text { berkaitan } \\
\text { dengan tingkat } \\
\text { kepatuhan dan } \\
\text { penerimaan } \\
\text { pajak }\end{array}$ & $\begin{array}{l}\text { Peneliti sebelumnya } \\
\text { menggunakan } \\
\text { kepatuhan wajib } \\
\text { pajak badan dan } \\
\text { objek tempat yang } \\
\text { berbeda. }\end{array}$ \\
\hline
\end{tabular}

\section{Hipotesis Penelitian}

Hipotesis merupakan jawaban sementara terhadap rumusan masalah penelitian, oleh karena itu rumusan masalah penelitian biasanya disusun dalam bentuk kalimat. Berdasarkan latar belakang permasalahan yang ada, maka hipotesis dalam penelitian ini adalah :

H1 : Tingkat Kepatuhan wajib pajak orang pribadi berpengaruh signifikan terhadap penerimaan PPh Pasal 25 orang pribadi di Kantor Pelayanan Pajak Pratama Bitung.

\section{Jenis Penelitian}

\section{METODE PENELITIAN}

Data adalah keterangan mengenai sesuatu yang diperoleh dalam suatu penelitian untuk menjelaskan, menerangkan dan memecahkan masalah-masalah sesuai dengan konteks judul yang diambil dengan maksud tujuan tersebut.

\section{Penelitian Eksploratif (Eksploratory Research)}

Penelitian eksploratif (eksploratory research) adalah penelitian yang bertujuan untuk mengembangkan pengetahuan atau dugaan yang sifatnya masih baru dan untuk memberikan arahan bagi penelitian selanjutnya.

\section{Penelitian konklusif (Conclusive Research)}

Penelitian konklusif (conclusive research) adalah penelitian yang bertujuan untuk menguji atau membuktikan sesuatu dan untuk membantu peneliti dalam memilih tindakan khusus selanjutnya. Penelitian konklusif dibagi menjadi 2 (dua) jenis, yaitu studi deskriptif (descriptive study) dan studi eksperimen (eksperimental study). Jenis penelitian yang digunakan dalam penelitian ini adalah penelitian konklusif dengan menggunakan studi eksperimental, dimana penelitian ini bertujuan untuk memperoleh pengujian yang tepat dalam menarik kesimpulan hubungan sebab akibat antar variabel.

\section{Teknik Pengumpulan Data}

1. Survey 
Peneliti akan melakukan pengamatan langsung ke obyek penelitian untuk mendapatkan dan mencatat data yang diperlukan, yaitu pada Kantor Pelayanan Pajak.

2. Interview

Pengumpulan data dengan melakukan wawancara dengan pegawai-pegawai pemerintah yang bertugas di Kantor Pelayanan Pajak yang dapat memberikan informasi untuk keperluan penelitian.

3. Dokumentasi

Pengumpulan data dengan cara menyalin laporan, data maupun catatan yang berkaitan dengan pelaporan SSP masa yang masuk tepat waktu dan penerimaan pajak dan data-data lain yang diperlukan dalam penelitian ini.

\section{Metode Analisis}

Metode analisis yang digunakan pada penelitian ini yaitu analisis regresi liniear sederhana dengan menggunakan program komputerisasi yaitu program SPSS 17 for Windows (Statistical Product and Service Solution). Program ini digunakan untuk mencari pengaruh variabel independent, yaitu Tingkat Kepatuhan Wajib Pajak Orang Pribadi, dengan variabel dependent yaitu Penerimaan Pajak PPh Pasal 25. Persamaan umum regresi liniear sederhana adalah sebagai berikut.

$\mathrm{Y}=\mathrm{a}+\mathrm{bX}$

Dimana:

$\mathrm{Y} \quad=$ Penerimaan Pajak Penghasilan Pasal 25

a $\quad=$ Nilai konstanta

$\mathrm{b} \quad=$ Koefisien regresi

$\mathrm{X} \quad=$ Tingkat Kepatuhan Wajib Pajak Orang Pribadi.

Uji Asumsi Klasik

Pengujian Asumsi Klasik bertujuan untuk memperoleh model regresi yang menghasilkan estimator liniear tidak bias yang terbaik (Best Linier Unbiased Estimator/ BLUE). Pengujian asumsi klasik yang dilakukan yaitu sebagai berikut.

1. Uji Normalitas

Uji normalitas data yang digunakan untuk melakukan pengujian data observasi apakah data tersebut berdistribusi normal atau tidak. Ada cara yang biasa digunakan untuk menguji normalitas pada model regresi yaitu dengan uji Kolmogorov Smirnov. Uji normalitas dengan uji Kolmogorov Smirnov, konsep dasar dari uji Kolmogorov Smirnorv adalah dengan membandingkan distribusi data (yang akan diuji normalitasnya) dengan distribusi normal baku.

\section{Uji Autokorelasi}

Uji autokorelasi adalah terjadinya hubungan antara variabel independent digunakan untuk suatu tujuan yaitu mengetahui ada tidaknya korelasi antar anggota serangkaian data yang diobservasi dan dianalisis menurut ruang atau menurut waktu, cross section atau time series.

3. Uji Heteroskedastisitas

Semua model dikatakan memiliki problem heteroskedastisitas berarti ada atau terdapat varian variabel dalam model yang tidak sama. Gejala ini dapat pula diartikan bahwa dalam model terjadi ketidaksamaan varian dari residual pada pengamatan model regresi tersebut.

Uji Regresi Linier Sederhana

1. Uji t

Dilakukan unutk mengetahui pengaruh variabel independen secara individu (parsial) terhadap variabel independen.

2. Korelasi dan Determinasi

Korelasi adalah mengukur keeratan suatu hubungan, keeratan suatu hubungan ini dinyatakan dengan besaran nilai korelasi (R) yang nilainya berada dalam rentang -1 sampai dengan 1 (Thrihendradi, 2009 : 197).

\section{HASIL PENELITIAN DAN PEMBAHASAN \\ Deskripsi Pengaruh Tingkat Kepatuhan Wajib Pajak Orang Pribadi Terhadap Penerimaan Pajak di KPP Pratama Bitung}

Tingkat kepatuhan wajib pajak orang pribadi dilihat dari Jumlah Surat Setoran Pajak (SSP) masa yang masuk tepat waktu dan penerimaan pajak di KPP Pratama Bitung dari tahun 2009 sampai dengan tahun 2012 masih rendah. Bisa dilihat dari tabel 1.2 dimana pada tahun 2009 wajib pajak yang terdaftar sebesar 44.319 dan wajib pajak yang membayar pajak hanya 8.152 atau $18 \%$ wajib pajak yang membayar pajak. Dan pada tahun 
2010 sampai dengan 2011 mengalami peningkatan dalam wajib pajak membayar pajaknya, jumlah wajib pajak yang terdaftar 2010 sebesar 14.084 dan yang membayar pajaknya sebesar 11.201 atau $79 \%$ dari wajib pajak membayar pajaknya dan pada tahun 2011 wajib pajak yang terdaftar membayar pajaknya mencapai $97 \%$ dilihat dari wajib pajak yang membayar pajak sebesar 10.213 dan membayar pajak sebesar 9.996 tapi di tahun 2012 mengalami penurunan dari wajib pajak terdaftar sebesar 6.355 dan yang membayar pajaknya 5.322 atau $83 \%$ wajib pajak yang membayar pajaknya. Maka dapat disimpulkan bahwa tingkat kepatuhan wajib pajak orang pribadi di kantor pelayanan pajak pratama Bitung masih rendah.

\section{Pembahasan}

\section{Analisis Statistik}

1. Hasil uji Asumsi klasik

a. Uji Normalitas

Uji normalitas digunakan guna mengetahui apakah nilai residu (perbedaaan yang ada) yang diteliti memiliki distribusi normal atau tidak normal. Dengan menggunakan data yang sudah ada, penulis akan melakukan uji normalitas dengan menggunakan uji kolmogorov smirnov . Uji Kolmogorov Smirnov dengan kaidah keputusan jika nilai sig lebih besar dari 0,05 (taraf kesalahan 5\%), maka dapat dikatakan residual model berdistribusi normal. Diambil keluaran yang ada nilai kolmogorov smirnov pada tabel Test of Normality sebagai berikut :

\section{Tabel 2. Uji Normalitas}

Tests of Normality

\begin{tabular}{|c|c|c|c|c|c|c|}
\hline & \multicolumn{3}{|c|}{ Kolmogorov-Smirnov $^{\mathrm{a}}$} & \multicolumn{3}{|c|}{ Shapiro-Wilk } \\
\hline & Statistic & df & Sig. & Statistic & $\mathrm{df}$ & Sig. \\
\hline Unstandardized Residual & .10 & 4 & .20 & .89 & 4 & .011 \\
\hline
\end{tabular}

(sumber : Hasil olah SPSS)

Hasil output di atas, dapat dilihat bahwa uji kolmogorov smirnov nilai sig sebesar 0,011 lebih besar dari dari 0,05 didasarkan pada ketentuan, maka data berdistribusi normal

b. Uji Autokorelasi

Uji Durbin-Watson digunakan untuk melihat apakah terdapat autokorelasi atau tidak pada tabel output Model Summary.

Tabel. 3. Uji Autokorelasi

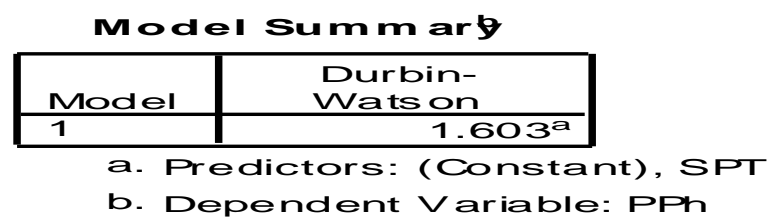

(sumber : Hasil olah SPSS)

Suatu model dapat dinyatakan tidak terjadi gejala autokorelasi, jika probabilitas nilai Durbin-Watson lebih dari 0,05. Pada tabel 3. Model Summary di atas probabilitas nilai Durbin-Watson adalah 1,603, angka tersebut 1,603 0,05. Maka dapat dipastikan bahwa model tersebut tidak mengalami gejala autokorelasi.

c. Uji Heteroskedistisitas

Penelitian ini untuk menguji heteroskedastitas akan digunakan uji Glesyer. Pada tabel dibawah ini merupakan hasil output Coefficient untuk menguji heteroskedastisitas. 


\section{Coefficents}

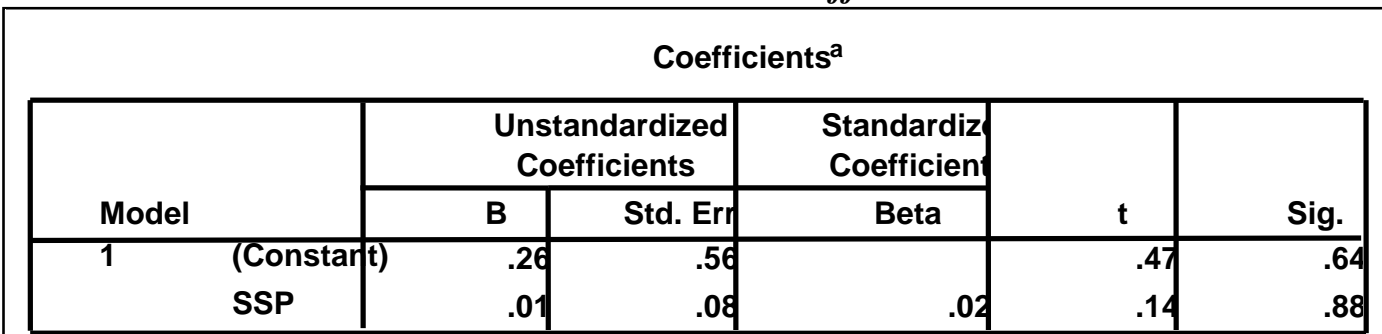

a. Dependent Variable: AR

(sumber : Hasil olah SPSS)

Suatu model dapat dikatakan tidak mengalami gejala heteroskedastisitas jika nilai probabilitas atau signifikasi 0,05 . Tabel 4. di atas menunjukan bahwa probabilitas atau taraf signifikasi memiliki nilai sebesar 0,888. Dengan menggunkan uji Glesyer , maka variabel independen memiliki tingkat signifikasi diatas 0,05 terhadap absolut residualnya sehingga dapat disimpulkan bahwa varians data penelitian tidak terjadi efek heteroskedistisitas.

2. Hasil Uji Regresi Linier Sederhana

a. Uji t

Hasil uji pengaruh tingkat kepatuhan wajib pajak orang pribadi terhadap jumlah penerimaan pajak $\mathrm{PPh}$ pasal 25 dapat dilihat pada tabel 5. di bawah ini.

Tabel 5. Uji t

Coefficients

\begin{tabular}{|c|c|c|c|c|c|c|}
\hline \multirow{2}{*}{\multicolumn{2}{|c|}{ Model }} & \multicolumn{2}{|c|}{$\begin{array}{l}\text { Unstandardized } \\
\text { Coefficients }\end{array}$} & \multirow{2}{*}{$\begin{array}{c}\text { Standardized } \\
\text { Coefficients }\end{array}$} & \multirow[b]{2}{*}{$\mathrm{t}$} & \multirow[b]{2}{*}{ Sig. } \\
\hline & & $\mathrm{B}$ & Std. Error & & & \\
\hline & $\begin{array}{l}\text { (Cons tant) } \\
\text { SSP }\end{array}$ & $\begin{array}{r}18.453 \\
.070\end{array}$ & $\begin{array}{l}.859 \\
.131\end{array}$ & .079 & $\begin{array}{r}21.485 \\
.538\end{array}$ & $\begin{array}{l}.000 \\
.593\end{array}$ \\
\hline
\end{tabular}

a. Dependent Variable: PPh

(Sumber : Hasil olah SPSS)

Hipotesis yang telah dirumuskan :

$\mathrm{H}_{0} \quad$ 0,Tingkat Kepatuhan Wajib Pajak Orang Pribadi tidak berpengaruh signifikanterhadap Penerimaan Pajak Pasal 25 Orang Pribadi di KPP Pratama Bitung.

Ha 0, Tingkat Kepatuhan Wajib Pajak Orang Pribadi berpengaruh signifikan terhadap Penerimaan Pajak Pasal 25 Orang Pribadi di KPP Pratama Bitung.

Dengan ketentuan pada uji t sebagai berikut :

1. Berdasarkan perbandingan dengan

a. Jika maka $\mathrm{H}_{0}$ ditolak dan Ha diterima.

b. Jika , maka $\mathrm{H}_{0}$ diterima dan Ha ditolak

Hasil output tabel 5. Coefficients di atas, nilai yaitu variabel tingkat kepatuhan wajib pajak orang pribadi dilihat dari surat setoran pajak (SSP) yang masuk tepat waktu adalah sebesar 0,538 dan yang menggunakan degree of freedom (df) jumlah data -2-1 atau 42-1-2=40 maka hasil yang diperoleh sebesar 1,683 (dilihat pada lampiran) sehingga atau 0,538 1,683, maka $\mathrm{H}_{0}$ diterima dan Ha ditolak.

2. Berdasarkan tingkat signifikasi

a. Jika signifikasi/probabilitas 0,05 maka $\mathrm{H}_{0}$ ditolak dan Ha diterima. .

b. Jika signifikasi/probabilitas $\quad 0,05$ maka $\mathrm{H}_{0}$ diterima dan Ha ditolak.

Berdasarkan tingkat signifikasi maka variabel tingkat kepatuhan wajib pajak orang pribadi dilihat dari surat setoran pajak (SSP) yang masuk tepat waktu sebesar 0,593. Sehingga nilai signifikasi $0,593 \quad 0,05$ maka $^{\mathrm{H}_{0}}$ diterima, Ha ditolak artinya tingkat kepatuhan wajib pajak orang pribadi tidak berpengaruh signifikan terhadap penerimaan PPh pasal 25 orang pribadi di KPP Pratama Bitung. Hal ini menunjukan bahwa hipotesis yang menduga bahwa tingkat kepatuhan wajib pajak orang pribadi berpengaruh signifikan terhadap penerimaan pajak PPh pasal 25 di KPP Pratama Bitung adalah tidak terbukti.

a. Uji Koefisien Korelasi dan Determinasi (Uji R dan ) 
Untuk melihat besarnya koefisien korelasi dan determinasi, yaitu dengan melihat tabel 6 hasil output Model Summary seperti terlihat dalam tabel berikut :

\section{Tabel 6. Uji Koefisien Korelasi dan Determinasi}

Model Sum mary

\begin{tabular}{|l|r|r|r|r|}
\hline Model & $\mathrm{R}$ & $\mathrm{R}$ Square & $\begin{array}{c}\text { Adjusted } \\
\text { R Square }\end{array}$ & $\begin{array}{c}\text { Std. Error of } \\
\text { the Estimate }\end{array}$ \\
\hline 1 & $.079^{\mathrm{a}}$ & .006 & -.015 & .47488 \\
\hline
\end{tabular}

a. Predictors: (Constant), SSP

Koefisien korelasi (R) yaitu sebuah nilai untuk mengukur keeratan hubungan antara variabel respon atau variabel dependen dengan variabel predictor atau variabel independent (penjelas), hubungan ini dinyatakan dengan besaran nilai korelasi (R) yang nilainya berada dalam rentang -1 sampai dengan 1. Angka koefisien $R$ yaitu 0,079 maka hubungan cukup kuat dan arah hubungan tersebut berkebalikan. Koefisien determinasi ( $R$ Square) yaitu nilai yang digunakan untuk melihat sejauh mana model yang terbentuk dapat menjelaskan kondisi sebenarnya. Angka R square yaitu 0,006 merupakan angka pengkuadratan dari koefisien korelasi atau ( $0.079 \mathrm{x}$ $0.079=0.006)$. $\mathrm{R}$ square biasa disebut dengan koefisien determinasi angka tersebut berarti $0.06 \%$ penerimaan PPh pasal 25 WPOP pada KPP di Bitung dpat dijelaskan oleh variabel tingkat kepatuhan WPOP, sedangkan sisanya $(100 \%-0.06 \%=99,94 \%)$ disebabkan oleh faktor atau variabel-variabel lain yang tidak dimasukkan dalam penelitian ini.

\section{Pembahasan Pengaruh Tingkat Kepatuhan Wajib Pajak Orang Pribadi Terhadap Penerimaan Pajak}

Pajak adalah salah satu elemen penting untuk menyokong atau bahkan menyukseskan pembangunan di setiap kota atau provinsi, dikarenakan peranan penting dari penerimaan pajak untuk setiap sektor pembangunan, baik secara langsung maupun tidak langsung. Pajak selanjutnya bisa didapatkan dari setiap individu atau badan usaha yang ada/beroperasi di suatu kota atau provinsi, yang mana nominal dari setiap orang atau perusahaan/lembaga tersebut bisa sangat bervariasi. Penerimaan pajak tersebut akan bermanfaat untuk setiap rencana pembangunan yang ada di setiap kota atau provinsi, mulai dari pembangunan fisik fasilitas umum sampai dengan peningkatan pendidikan di daerah tersebut.

Sehubungan dengan peranan penting dari pajak untuk pembangunan suatu daerah, ada satu konsep khusus yang mesti diperhatikan oleh pemerintah provinsi atau pemerintah daerah di setiap kota atau provinsi di Indonesia, yaitu Kepatuhan Wajib Pajak Orang Pribadi. Hal ini menjadi penting karena di setiap kota atau provinsi pasti terdapat banyak orang dengan pekerjaan yang berbeda-beda dan akan menyetorkan nominal pajak yang tidak sama setiap bulan atau tahun. Kepatuhan Wajib Pajak Orang Pribadi selanjutnya mempengaruhi oleh Penerimaan pajak. Secara khusus, hubungan penting di antara Kepatuhan Wajib Pajak Orang Pribadi dengan penerimaan pajak dari masyarakat yang ada di Kota Bitung.

Hasil penelitian ini menyatakan bahwa hubungan antara Kepatuhan Wajib Pajak Orang Pribadi dengan penerimaan pajak tidak berpengaruh signifikan. Berdasarkan hasil analisis uji parsial Orang Pribadi terhadap penerimaan pajak pada KPP di Bitung dengan tingkat probabilitas adalah 0,593 itu berarti $\mathrm{H}_{0}$ diterima artinya tingkat kepatuhan tidak berpengaruh signifikan terhadap penerimaan pajak. Hal ini disebabkan karena masih kurang adanya kesadaran masyarakat di kota tersebut terhadap pentingnya membayar pajak secara tepat waktu dan jumlah surat setoran pajak (SSP) yang masuk tepat waktu terdapat laporan perhitungan pajaknya yang nihil. Tapi kewajiban untuk membayar lunas perhitungan atas jumlah pajak yang terhutang tetap dibayar oleh WPOP.

Hasil dari koefisien determinasi disesuaikan ( $R$ Square) sebesar 0,06 \%. Dari hasil tersebut maka dapat disimpulkan bahwa penerimaan PPh pasal 25 orang pribadi di KPP Bitung mempengaruhi variabel tingkat kepatuhan wajib pajak orang pribadi sebesar 0.006 sedangkan sisanya dipengaruhi oleh faktor-faktor atau variabel lain di luar penelitian ini.

\section{Kesimpulan}

\section{PENUTUP}

Kesimpulan penelitian ini adalah sebagai berikut :

1. Kepatuhan wajib pajak orang pribadi yang diukur dengan jumlah surat setoran pajak (SSP) yang masuk tepat waktu tidak berpengaruh signifikan terhadap penerimaan pajak.

2. Tingkat Kepatuhan tidak berpengaruh signifikan terhadap penerimaan pajak hal ini disebabkan karena masih kurangnya kesadaran masyarakat dikota tersebut terhadap pentingnya membayar pajak secara tepat waktu dan jumlah surat setoran pajak (SSP) yang masuk tepat waktu terdapat laporan perhitungan pajaknya yang 
nihil tetapi kewajiban untuk membayar lunas perhitungan atas jumlah pajak yang terhutang tetap dibayar oleh wajib pajak orang pribadi (WPOP).

3. Penerimaan PPh pasal 25 orang pribadi di KPP Bitung mempengaruhi variabel tingkat kepatuhan wajib pajak orang pribadi sebesar 0.006 sedangkan sisanya dipengaruhi oleh faktor-faktor atau variabel lain di luar penelitian ini.

\section{Saran}

Saran yang dapat diberikan setelah melakukan peneltian ini yaitu peningkatan mutu pelayanan aparat pajak pada KPP Pratama Bitung yang berarti bahwa aparat pajak harus memudahkan wajib pajaknya untuk dapat memenuhi kewajibannya. Misalnya meningkatkan sosialisasi dalam pembayaran pajak dengan menggunakan teknologi sehingga wajib pajak lebih memahami dan mudah untuk menggunakan teknologi dalam membayar pajak. Dan terhadap wajib pajak terdaftar tetapi tidak dimasukkan kembali agar dikenai sanksi denda administrasi dan aparat lebih tegas dalam memberikan sanksi.

\section{DAFTAR PUSTAKA}

Casavera. 2009. Perpajakan. Graha ilmu. Yogyakarta.

Lainutu, Amina. 2013. Pengaruh Jumlah Wajib Pajak PPh Pasal 21 Terhadap Penerimaan PPh Pasal 21 Pada KPP Pratama Manado. Skripsi. Universitas Sam Ratulangi. Manado.

Lubis, Ardiansyah.,Gustian, Djuanda. 2010. Review Pajak Orang Pribadi dan Orang Asing. Salemba Empat . Jakarta.

Pangemanan, Rima Naomi. 2013. Hubungan Jumlah dan Kepatuhan Wajib Pajak Badan Dengan Penerimaan PPh KPP Pratama Manado. Skripsi. Universitas Sam Ratulangi. Manado.

Pudyatmoko, Sri Y. 2009. Pengantar Hukum Pajak. Andi. Yogyakarta.

Rahman, Abdul. 2010. Panduan Pelaksanaan Administrasi Perpajakan Untuk Karyawan, Pelaku Bisnis Dan Perusahaan. Nuansa. Bandung.

Sumarsan, Thomas. 2012. Perpajakan Indonesia : Pedoman Perpajakan Yang Lengkap Berdasarkan UndangUndang Terbaru. Edisi 2. Indeks. Jakarta.

Waluyo. 2011. Perpajakan Indonesia. Edisi 10. Salemba Empat. Jakarta.

Widyaningsih, Aristanti. 2011. Hukum Pajak Dan Perpajakan. Alfabeta. Bandung.

Trihendradi, C. 2009. 7 Langkah Mudah Melakukan Analisis Statistik Menggunakan SPSS 17. Andi. Yogyakarta. 